Revista del Centro de Investigación de la Universidad La Salle

Vol. 14, No. 56, Julio-Diciembre, 2021: 205-233

DOI: http://doi.org/10.26457/recein.v14i56.2870

\title{
Tourism sustainability in a Protected Area: Case Loreto Bay National Park
}

\section{Sustentabilidad del turismo en un Área Protegida: Caso Parque Nacional Bahía de Loreto}

Iris del Castillo Velasco Martínez Centro de Investigaciones Biológicas del Noroeste (México)

Luis Felipe Beltrán-Morales Centro de Investigaciones Biológicas del Noroeste (México)

Gerzaín Avilés-Polanco Cátedra CONACYT-Centro de Investigaciones Biológicas del Noroeste (México)

Reyna María Ibáñez-Pérez Universidad Autónoma de Baja California Sur (México)

Gustavo Alberto Arnaud-Franco Centro de Investigaciones Biológicas del Noroeste (México) Ángel Herrera-Ulloa Universidad Nacional de Costa Rica (Costa Rica) Alfredo Ortega-Rubio Centro de Investigaciones Biológicas del Noroeste (México)

Recibido: 10 de febrero de 2021

Aceptado: 31 de marzo de 2021

Publicado: 10 de noviembre 2021

\section{Resumen}

El objetivo de este estudio fue evaluar la tendencia del desempeño del turismo sostenible en el Parque Nacional Bahía de Loreto en Baja California Sur, México y sus áreas de influencia, cubriendo el período 2007-2017. Para ello se seleccionaron indicadores de la dimensión socioeconómica, turística, ambiental y tecnológica. Los datos se obtuvieron a partir de búsquedas bibliográficas, así como de entrevistas

"Email: aortega@cibnor.mx

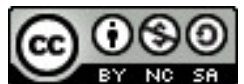

Revista del Centro de Investigación. Universidad La Salle por Dirección de Investigación. Universidad La Salle Ciudad de México se distribuye bajo una Licencia Creative Commons Atribución-NoComercial-CompartirIgual 
del Castillo Velasco Martínez, I.; Beltrán-Morales, L. F.; Avilés-Polanco, G.; Ibáñez-Pérez, R. M.; Arnaud-Franco, G. A.; Herrera-Ulloa, Á. ; Ortega-Rubio, A.

con tomadores de decisiones y operadores turísticos, calculando los índices de sostenibilidad para cada dimensión y el índice general de sostenibilidad. Se realizaron análisis de correlación y de componentes principales para determinar el grado de contribución de cada indicador a la sostenibilidad. Los resultados indicaron un incremento en la sostenibilidad. Sin embargo, uno de los principales obstáculos durante este estudio fue la disponibilidad de información a nivel municipal y más aún a nivel de áreas protegidas. El modelo propuesto puede contribuir en la toma de decisiones sobre la gestión de un área protegida con visitantes. El estudio concluye con una serie de recomendaciones y aportaciones del método.

Palabras clave: Índice; indicadores; análisis multivariado; turismo de naturaleza; series de tiempo. 


\section{Abstract}

The aim of this study was to evaluate the sustainable tourism performance trend in Loreto Bay National Park in Baja California Sur, Mexico and its areas of influence, covering from 2007-2017. For this purpose, indicators of socioeconomic, tourism, environmental and technological dimensions were selected. Data was obtained from bibliographic searches, as well as interviews with decision- makers and tourism operators, calculating sustainability indexes for each dimension and the general sustainability index. Correlation and principal component analyses were performed to determine the contribution degree of each indicator to sustainability. The results indicated that sustainability had increased. However, one of main obstacles during this study was information availability at municipal level and even more at protected area level. Thus, the proposed model may contribute in decision-making about managing a protected area with visitors. The study concludes with a series of recommendations and method contributions.

Keywords: Index; indicators; multivariate analysis; nature-based tourism; time series. 
del Castillo Velasco Martínez, I.; Beltrán-Morales, L. F.; Avilés-Polanco, G.; Ibáñez-Pérez, R. M.; Arnaud-Franco, G. A.; Herrera-Ulloa, Á.; Ortega-Rubio, A.

\section{Introduction}

Tourism is one of the fastest growing economic sectors worldwide, which had recorded eight years of consecutive growth (CNET (Consejo Nacional Empresarial Turístico), 2018). In the case of Mexico, 39.3 million international tourists were received in 2017, placing it in sixth place among the 10 main tourist destinations worldwide (OMT (Organización Mundial del Turismo), 2018). Demand for nature-based tourism keeps increasing and visitors are willing to pay a higher cost from $2-40 \%$ for receiving environmentally-friendly services (Balmford et al., 2009; UNWTO (United Nations Environment Programme and World Tourism Organization), 2012; Winter et al., 2020). Protected areas (PA) are the main destinations for this type of tourism (CONANP (Comisión Nacional de Áreas Naturales Protegidas) \& SEMARNAT (Secretaría del Medio Ambiente y Recursos Naturales), 2007; Eagles, 2014; R. M. Ibáñez Pérez, 2014)el estudio, discusión e investigación del fenómeno turístico y recreativo en las Áreas Protegidas ha ido acrecentándose también en foros y organismos internacionales. Actualmente esta clase de turismo ha sido reconocido en diversas convenciones y declaraciones como una oportunidad de desarrollo sustentable. Sin embargo esta actividad puede amenazar al patrimonio natural y al cultural, pues se han registrado experiencias internacionales que demuestran que ésta causa impactos negativos en el contexto natural, social e incluso económico de las Áreas Protegidas - por la infraestructura y los proyectos turísticos no planificados, o por visitaciones no reguladas ni programadas. Este crecimiento en visitación, así como el interés por manejarlo apropiadamente, es un fenómeno que también se replica en México dentro de las Áreas Protegidas Federales (APF. According to Balmford et al. (2015), terrestrial PA worldwide had received 8 billion visits per year and Mexico received 2.8 million tourists in terrestrial and aquatic PA in 2017 (CONANP 2018).

Appropriate management and nature-based tourism in a PA could be considered driving factors for the destination sustainable development (Dwyer \& Edwards, 2000; Kim et al., 2019; Siikamäki et al., 2015; Snyman \& Bricker, 2019). However, tourism poses also potential threats to the environment and host population, such as air and water pollution, habitat fragmentation, alterations in wildlife behavior and physiology, congestion, crime and changes in the host community culture (Almeida García et al., 2015; Andereck et al., 2005; Buckley, 2011; Eagles et al., 2002; Jones et al., 2017; Monz et al., 2013; Stronza et al., 2008). Such negative effects have highlighted the importance of achieving sustainable tourism goals and taking them as the basis for the creation of management policies for the area. According to the World Tourism Organization (OMT 2012) these goals consist of satisfying the needs of visitors, industry, and host communities, considering current and future social and environmental effects.

In a periodic evaluation of a tourist destination, sustainability is essential to know the progress and impacts that tourism has generated on the environment and socioeconomic sector. Sustainability indicators are measurement tools or parameters that provide specific information about a phenomenon and allow defining objectives, challenges or demonstrating progress (Astier et al., 2008). Aggregate sustainability indexes or composite indicators are used to integrate and analyze the information of indicators (Mayer, 2008; Saisana \& Tarantola, 2002; Schuschny \& Soto, 2009). Through a representative and easy to understand value, the indexes allow comparing the systems studied annually and collaborating in decision-making about their management (Nardo \& Saisana, 2005). 
The selection of tourism sustainability indicators -even more their application- are complex processes (Asmelash \& Kumar, 2019; Blancas et al., 2016; Tanguay et al., 2013). This complexity is reflected in variety of the indicator systems reported in scientific publications (Ashok et al., 2017; Choi \& Sirakaya, 2006; Hashemkhani Zolfani et al., 2015; Li, 2004; Singh et al., 2009; Torres-Delgado \& Saarinen, 2013; Tsaur et al., 2006; Xin \& Chan, 2014) and international organization reports (WTO (World Tourism Organization) 2004; OMT 2005). Some of these systems require a great amount of information, in addition to a complex analysis method, which hinder their application and decision-making by political actors (Tanguay et al., 2013). Indicators are not universal - they depend on the study objectives, as well as availability and access to information (Astier et al., 2008). For regional or local studies, developing a list of specific indicators is a priority; such is the case of PA, marginalized areas, municipalities and coastal communities in which one of main obstacle is scarce information (Castellani \& Sala, 2010; Herrera-Ulloa et al., 2003; R. Ibáñez Pérez, 2015).

This study proposes a model to evaluate the sustainable performance trend of a PA with tourism activities over a period of time, which consists of a list of indicators; in addition, a simple and detailed analysis method serves as a replicable model and collaborates in managing these tourism destinations. The study area was Loreto Bay National Park (LBNP) and its areas of influence. The analyzed period covered from 2007-2017.

\section{Methods}

\subsection{Study area}

The municipality of Loreto is located in the State of Baja California Sur (BCS), Mexico. In 2015 its population was 18912 inhabitants, of which $88 \%$ was distributed in the municipal seat that bears the same name (GBCS (Gobierno de Baja California Sur), 2018). The productive activities in the region are agriculture, livestock, and fisheries, but tourism represents the main economic activity (Hernández Trejo et al. 2009; GBCS 2018). Hotels and restaurants are the main source of employment, while commerce is the activity that generates the most economic gains (GBCS 2018). Loreto has become an important tourist destination worldwide. In 2016 and 2017 the site experienced an increase in tourist influx (national and international) (INEGI (Instituto Nacional de Estadística y Geografía) 2016; INEGI 2017).

The LBNP covers a total surface area of 206580.75 ha located off the coast of Loreto in the Gulf of California. This PA is characterized by a high biodiversity and endemism, which makes it one of the main tourist attractions in the region (CONANP 2002). Within the polygon, the Coronados, del Carmen, Danzante, Montserrat, and Santa Catalina islands are found, in addition to 12 islets (Figure 1). The populations that inhabit the localities in the area of influence - Loreto, San Cosme, Ensenada Blanca, Ligüí, Nopoló, and Agua Verde - depend mainly on the natural resources of the PA. This National Park has an updated Management Program, which establishes its zoning and regulation of tourism activities (DOF (Diario Oficial de la Federación) 2019).

However, tourism in LBNP may cause environmental damage, such as pollution and modification of 
del Castillo Velasco Martínez, I.; Beltrán-Morales, L. F.; Avilés-Polanco, G.; Ibáñez-Pérez, R. M.; Arnaud-Franco, G. A.; Herrera-Ulloa, Á.; Ortega-Rubio, A.

the natural landscape and behavior of some species (CONANP 2002) besides generating socio-economic and cultural costs to residents (Mendoza Ontiveros \& González Sosa, 2014).

Figure 1.

Location of Loreto Bay National Park and its areas of influence in Loreto Municipality, Baja California Sur, Mexico.

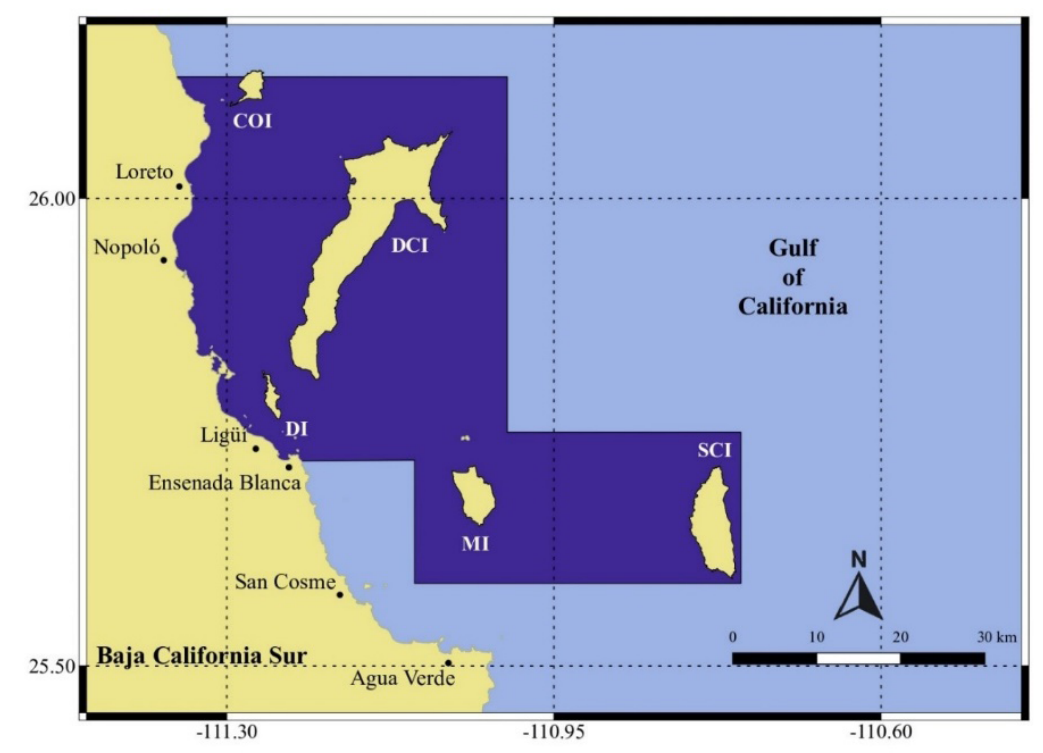

Abbreviations correspond to the names of the islands: (COI) Coronados Island; (DCI) Del Carmen Island; (DI) Danzante Island; (MI) Monserrat Island; (SCI) Santa Catalina Island. Source: Own production based on CONANP (2002).

\subsection{Selection of dimensions and indicators}

The selection of indicators and dimensions was performed through a review of proposed systems to evaluate sustainable development in Mexico and tourism in a PA (INEGI \& [INE] Instituto Nacional de Ecología 2000; OMT 2005; Santana-Medina et al. 2013). The incorporation of indicators into the index was defined by relevance, availability, reliability and sensitivity criteria (OMT 2005). Availability of information was the criterion that discarded a greater number of variables. Finally, 28 indicators were selected and organized in four dimensions: socio-economic, tourism, environmental and technological (Table 1). 
Table 1.

Sustainability indicators selected for Loreto Bay National Park (LBNP), Baja California Sur, Mexico and its areas of influence.

\begin{tabular}{|c|c|c|}
\hline Dimension & Indicator & Relationship with sustainability \\
\hline \multirow{8}{*}{$\begin{array}{l}\text { Socio-econo- } \\
\text { mic }\end{array}$} & Birthrate & + \\
\hline & Population growth & + \\
\hline & Child mortality & - \\
\hline & Working population & + \\
\hline & Literacy & + \\
\hline & Piped water & + \\
\hline & Homes without overcrowding & + \\
\hline & $\begin{array}{l}\text { Locations with more than } 5000 \\
\text { inhabitants }\end{array}$ & + \\
\hline \multirow[t]{9}{*}{ Tourist } & Tours to islands & + \\
\hline & Kayak services & + \\
\hline & Recreational diving & + \\
\hline & Resident tourism companies & + \\
\hline & Hotel occupation & + \\
\hline & Influx of national tourists & + \\
\hline & Inflow of foreign tourists & + \\
\hline & Accommodation Offer & + \\
\hline & LBNP tourism demand & + \\
\hline \multirow[t]{7}{*}{ Environmental } & Urban solid waste generation & - \\
\hline & Recycling & + \\
\hline & Illicit activities & + \\
\hline & Surveillance & + \\
\hline & Environmental inspections & + \\
\hline & Environmental certifications & + \\
\hline & Budget & + \\
\hline \multirow[t]{4}{*}{ Technological } & $\begin{array}{l}\text { Alternative energy in tourism com- } \\
\text { panies }\end{array}$ & + \\
\hline & Wastewater treatment plants & + \\
\hline & $\begin{array}{l}\text { Capacity of wastewater treatment } \\
\text { plants }\end{array}$ & + \\
\hline & Surveillance cameras & + \\
\hline
\end{tabular}

Source: Own production. 
del Castillo Velasco Martínez, I.; Beltrán-Morales, L. F.; Avilés-Polanco, G.; Ibáñez-Pérez, R. M.; Arnaud-Franco, G. A.; Herrera-Ulloa, Á.; Ortega-Rubio, A.

Social and economic indicators were classified into a single dimension, in which the variables represented demographic characteristics, health, education, employment and housing, of which the last two represented economic activity (Copus \& Crabtree, 1996). Tourism dimension indicators covered supply and demand activities. Demand variables indirectly reflect income generation, so the economic component was also implicit in tourism dimension. The environmental dimension included impact and response indicators to LBNP and its areas of influence, which included surveillance and inspection actions, as well as budget received for PA conservation. These activities are carried out by management institutions of the area, so political issues are addressed. Technological dimension is not commonly incorporated into sustainability assessments, but it represents the way through which natural resources are obtained and transformed to meet the needs (Cabezas et al., 2003). Therefore, technology may positively influence tourism development through communication and transportation systems (Choi \& Sirakaya, 2006; WTO (World Tourism Organization), 2011).

\subsection{Information Collection}

Data were obtained from monitoring and records performed by Instituto Nacional de Estadística, Geografía e Informática (INEGI), Consejo Nacional de Población (CONAPO), Secretaría de Turismo (SECTUR), CONANP, Eco-Alianza de Loreto, Procuraduría Federal de Protección al Ambiente (PROFEPA) and Comisión Nacional del Agua (CONAGUA). This information was collected through five sources: (1) statistical yearbooks and strategic information documents; (2) data provided directly by the administrative office of the LBNP; (3) data provided by Eco-Alianza de Loreto, civil organization; (4) applications through the National Transparency Platform; and (5) censuses to resident tour operators in Loreto and Nopoló localities.

\subsection{Index construction and statistical analysis}

Annual indicator values were organized in a matrix. The treatment of missing information consisted of linear regressions to replace missing values in the socioeconomic indicators. The General Sustainability Index (GSI) calculation consisted of adapting a methodology of Human Development Index (HDI) (Anand \& Sen, 1994). The indicator values were standardized to unify magnitudes and make them comparable (Nardo \& Saisana, 2005). The relativization method was used based on maximum and minimum values observed within the time series data; each indicator took values from zero to one. Equation 1 was used for indicators with a positive relationship with sustainability, while for those with negative relationship, Equation 2 was used.

$$
I_{i}=\frac{(x-m)}{(M-m)}
$$

$$
I_{i}=\frac{(x-M)}{(m-M)}
$$

Where: 


$$
\begin{aligned}
& I_{i}=\text { Standardized value of each indicator } \\
& x=\text { Observed value of each indicator } \\
& m=\text { Minimum value of the indicator } \\
& M=\text { Maximum value of the indicator }
\end{aligned}
$$

The sustainability Index (SI) by dimension for each year was obtained by arithmetic average of each dimension indicator (Equation 3). The SI varies from zero to one. As value approaches one, the dimension has better performance and the sustainability level is higher.

$$
S I_{i}=\frac{1}{n} \sum_{i=1}^{n} I_{i}
$$

Where:

$$
\begin{aligned}
& I_{i}=\text { Standardized value of each indicator } \\
& n=\text { Number of indicators for each dimension }
\end{aligned}
$$

The sustainable performance trend during the period of study was analyzed using annual values of the GSI. Calculation of this index consisted of an additive aggregation method using the arithmetic average of the four SI, whose assigned weight was the same for the four dimensions (Equation 4). One of the conditions of this aggregation method was the absence of dependence or strong interaction between variables (Gan et al., 2017), which was fulfilled since the values corresponded to the SI of each dimension. GSI took values from zero to one.

$$
G S I=\frac{1}{N} \sum_{i=1}^{N} S I_{i}
$$

Where:

$$
\begin{aligned}
& N=\text { Number of dimensions } \\
& S I_{i}=\text { Sustainability Index of each dimension }
\end{aligned}
$$

Normality of data were tested using Shapiro Wilk. Given the non-normal distribution of the data, Spearman correlation matrices were performed to determine positive and negative relationships among the four-dimensional indicators (Daniel, 2008). Statistical significance was considered when $\alpha \leq 0.05$. Indicators with the greatest contribution to the SI were identified with the principal component analysis (PCA). The determination coefficient $\left(\mathrm{R}^{2}\right)$ was obtained by the squared factor loading of each indicator (Guerrero de Lizardi, 2008).

In ecological and sustainability indexes a high correlation is commonly found between indicators; although the indicators are correlated, they are relevant and contribute independently to the sustainability of the system (Dormann et al., 2013; Gan et al., 2017). The multiple regression analysis requires absence 
del Castillo Velasco Martínez, I.; Beltrán-Morales, L. F.; Avilés-Polanco, G.; Ibáñez-Pérez, R. M.; Arnaud-Franco, G. A. ; Herrera-Ulloa, Á. ; Ortega-Rubio, A.

of autocorrelation (Gujarati \& Porter, 2010); the PCA offers an alternative since one of its assumptions is that original variables are correlated to generate new non-collinear variables (Dormann et al., 2013). Prior to each PCA, a strong association between variables $(\alpha \leq 0.05)$ was tested using Barlett sphericity for each dimension. Kaiser-Meyer-Olkin (KMO) sample adequacy test with values greater than 0.5 indicated that the data was suitable for analysis (Guerrero de Lizardi, 2008). Statistical analyses and their graphic representation were performed using SPSS (Statistical Program for Social Sciences, 20 version) software.

\section{Results}

\subsection{Socioeconomic dimension}

Except for population growth and birth rate, the trend of socioeconomic indicators during the period was positive, which was reflected in an increase in SI (Figure 2). The PCA grouped the indicators into two principal components (PC), which together represented $84 \%$ variance of the data. According to $\mathrm{R}^{2}$, the indicator with the highest contribution to socioeconomic SI was literacy percentage (Table 2). Employment, education and housing indicators showed positive correlations between some tourism offer indicators (number of companies offering tourist services and number of resident tourism companies) (Table 7 in the Appendix).

Figure 2

Sustainability Index (SI) trend of socioeconomic dimension, from 2007-2017.

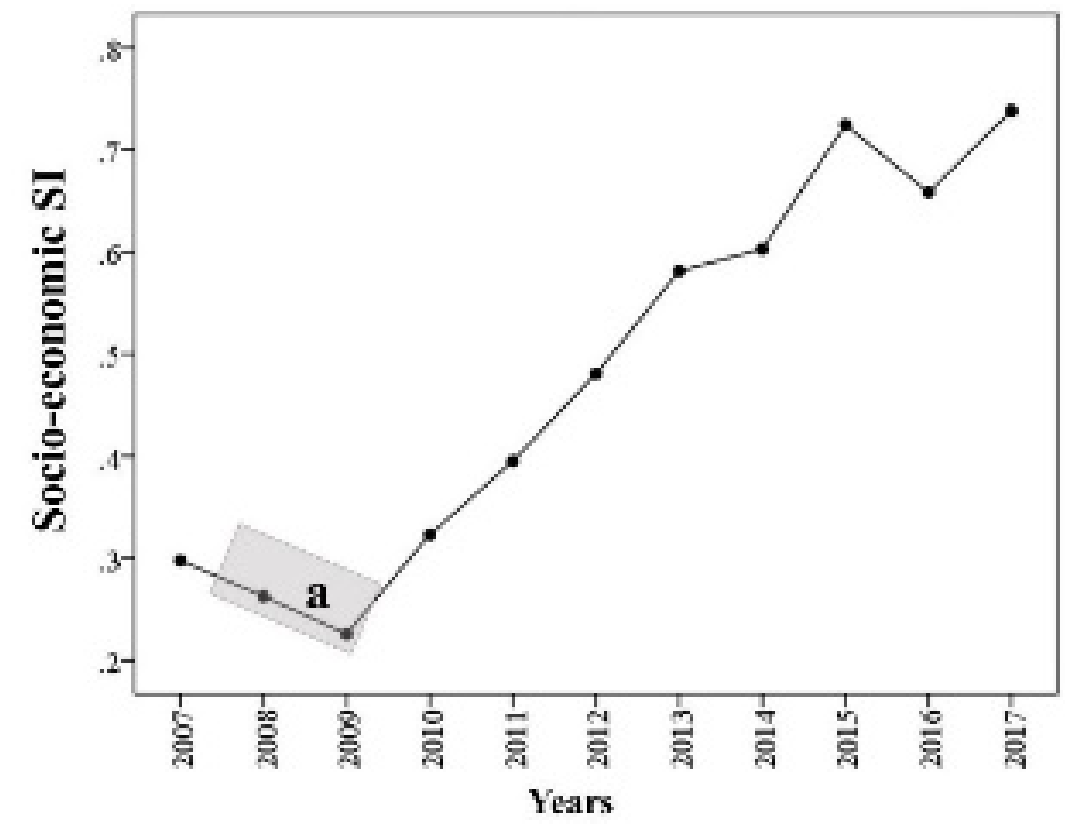

a) Infant mortality increases and population growth decrease. Source: authors' elaboration. 
Table 2.

Factor loadings of Principal Components $(P C)$ and determination coefficients $\left(R^{2}\right)$ for socioeconomic dimension in Loreto Bay National Park, Baja California Sur, México.

\begin{tabular}{l|c|c|c|}
\hline \multirow{2}{*}{ Indicators } & \multicolumn{2}{c}{ Factor loadings } & \multicolumn{2}{c}{$\mathrm{R}^{2}$} \\
& PC1 & PC2 & \multicolumn{1}{l}{} \\
\hline Birthrate & $\mathbf{- . 8 9 5}$ & -.275 & 0.805 \\
\hline Population growth & -.480 & .396 & 0.230 \\
\hline Child mortality & .268 & $\mathbf{. 8 6 6}$ & 0.072 \\
\hline Working population & $\mathbf{. 9 7 5}$ & -.032 & 0.951 \\
\hline Literacy & $\mathbf{. 9 8 9}$ & -.105 & 0.979 \\
\hline Piped water & $\mathbf{. 9 6 5}$ & -.010 & 0.932 \\
\hline Homes without overcrowding & $\mathbf{. 9 7 4}$ & -.122 & 0.948 \\
\hline Locations with more than 5000 inhabitants & $\mathbf{. 8 9 7}$ & -.027 & 0.805 \\
\hline
\end{tabular}

Factor loadings $>0.50$ were considered significant (in bold).

\subsection{Tourism dimension}

All tourism offer indicators showed a positive trend during the period of study and a positive correlation with the GSI (Table 6). The only demand indicator with positive trend was the number of tourists visiting the LBNP. The two PC accumulated variance of $87 \%$. The first component had a positive correlation with offer indicators and a negative one with two tourism demand indicators. In contrast, the second component showed a positive correlation with tourism demand indicators (Table 3). National tourist influx and hotel occupancy showed a negative trend during the period and a negative correlation with SI (Table 3; Figure 3). 
del Castillo Velasco Martínez, I.; Beltrán-Morales, L. F.; Avilés-Polanco, G.; Ibáñez-Pérez, R. M.; Arnaud-Franco, G. A.; Herrera-Ulloa, Á.; Ortega-Rubio, A.

Figure 3.

Sustainability Index (SI) trend of tourism dimension, from 2007-2017.

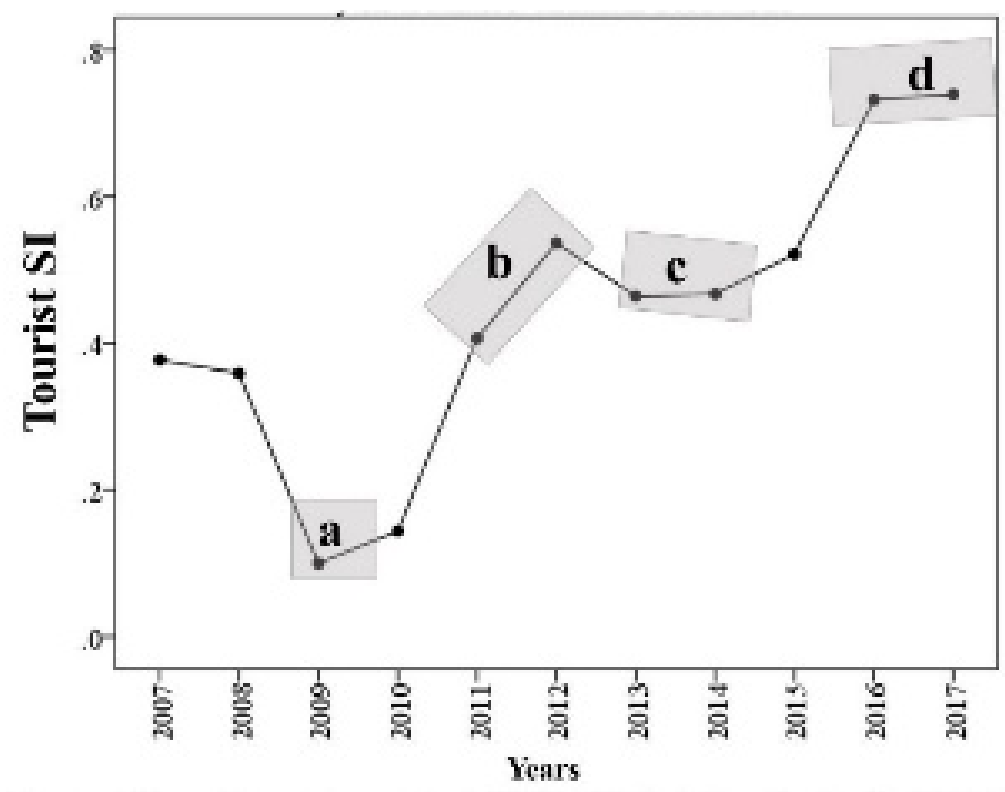

(a) Decrease in tourist influx and hotel occupancy due to economic crisis; (b) increase in tourism offer; (c) decrease in tourism offer and tourism influx; (d) increase in the number of visitors and the number of Loreto Bay National Park (LBNP) visitors. Source: authors' elaboration.

Table 3.

Factor loadings of Principal Components $(P C)$ and determination coefficients $\left(R^{2}\right)$ for tourism dimension in Loreto Bay National Park, Baja California Sur, México.

\begin{tabular}{|l|r|r|r|}
\hline \multirow{2}{*}{ Indicators } & \multicolumn{2}{c}{ Factor loadings } & \multicolumn{2}{c}{$\mathrm{R}^{2}$} \\
& PC1 & PC2 & \\
\hline Tours to islands & $\mathbf{. 9 5 9}$ & .220 & 0.9203 \\
\hline Kayak services & $\mathbf{. 9 5 6}$ & .197 & 0.9139 \\
\hline Recreational diving & $\mathbf{. 9 3 4}$ & .181 & 0.8720 \\
\hline Resident Tourism Companies & $\mathbf{. 9 1 3}$ & .225 & 0.8342 \\
\hline Hotel occupation & $\mathbf{- . 8 2 2}$ & $\mathbf{. 5 5 3}$ & 0.6763 \\
\hline Influx of national tourists & $\mathbf{. . 7 5 1}$ & $\mathbf{. 6 0 4}$ & 0.5634 \\
\hline Inflow of foreign tourists & -.064 & $\mathbf{. 9 6 9}$ & 0.0041 \\
\hline Accommodation Offer & $\mathbf{. 9 6 7}$ & .142 & 0.9345 \\
\hline LBNP tourism demand & .106 & $\mathbf{. 5 4 9}$ & 0.0112 \\
\hline
\end{tabular}

Factor loadings $>0.50$ were considered significant (in bold). 


\subsection{Environmental dimension}

Five of the seven environmental indicators showed a positive trend with irregular variations, which is reflected in the SI (Figure 4). The PCA grouped the indicators in four CP with a cumulative variance of $94.4 \%$. Indicators with the highest contribution to the SI were environmental certifications, followed by waste recycling and urban solid waste (USW) generation (Table 4). These three indicators also showed a positive correlation with the GSI (Table 4). Both illegal and surveillance actions decreased in 2015 and showed their peak in 2017 (Figure 4). Surveillance actions showed a negative correlation with the number of companies offering tourism tours (Table 7 in the Appendix).

Figure 4.

Sustainability Index (SI) trend of environmental dimension, from 2007-2017.

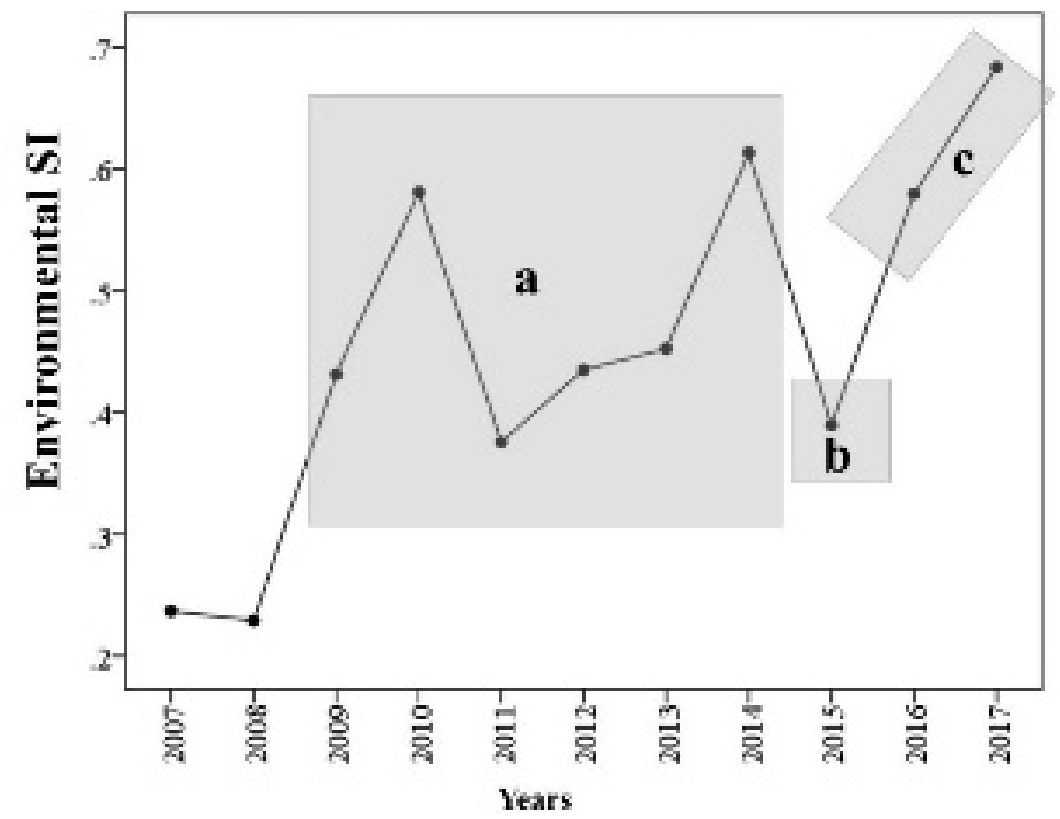

(a) Irregular variations; (b) decrease in surveillance and detection of illegal actions; (c) increase in surveillance, illegal actions and environmental certifications. Source: authors' elaboration.

Table 4.

Factor loadings of Principal Components $(P C)$ and determination coefficients $\left(R^{2}\right)$ for environmental dimension in Loreto Bay National Park, Baja California Sur, México.

\begin{tabular}{|c|c|c|c|c|c|}
\hline \multirow{2}{*}{ Indicators } & \multicolumn{4}{|c|}{ Factor loadings } & \multirow[t]{2}{*}{$\mathrm{R}^{2}$} \\
\hline & CP1 & CP2 & CP3 & CP4 & \\
\hline Urban solid waste generation & .786 & -.020 & .564 & .066 & 0.619 \\
\hline Recycling & .825 & -.039 & -.339 & .323 & 0.681 \\
\hline Illicit activities & .289 & .651 & -.358 & .571 & 0.084 \\
\hline
\end{tabular}


del Castillo Velasco Martínez, I.; Beltrán-Morales, L. F.; Avilés-Polanco, G.; Ibáñez-Pérez, R. M.; Arnaud-Franco, G. A.; Herrera-Ulloa, Á.; Ortega-Rubio, A.

\begin{tabular}{|l|r|r|r|r|r|}
\hline Surveillance & .217 & $\mathbf{. 7 7 2}$ & $\mathbf{. 5 2 2}$ & -.186 & 0.047 \\
\hline Environmental inspections & $\mathbf{- . 6 5 6}$ & $\mathbf{. 6 1 6}$ & -.228 & -.261 & 0.431 \\
\hline Environmental certifications & $\mathbf{. 9 3 4}$ & .065 & -.043 & -.260 & 0.873 \\
\hline Budget & $\mathbf{- . 5 8 8}$ & -.060 & .481 & $\mathbf{. 6 3 1}$ & 0.346 \\
\hline
\end{tabular}

Factor loadings $>0.50$ were considered significant (in bold).

\subsection{Technological dimension}

The four indicators considered in this dimension showed a positive trend, and three of them showed a positive correlation with the GSI (Table 6). The PCA generated only one PC with a variance of $80 \%$. The indicators that showed a higher correlation with the component were the number of wastewater treatment plants and their capacity (Table 5; Figure 5).

Figure 5.

Sustainability Index (SI) trend of technological dimension, from 2007-2017.

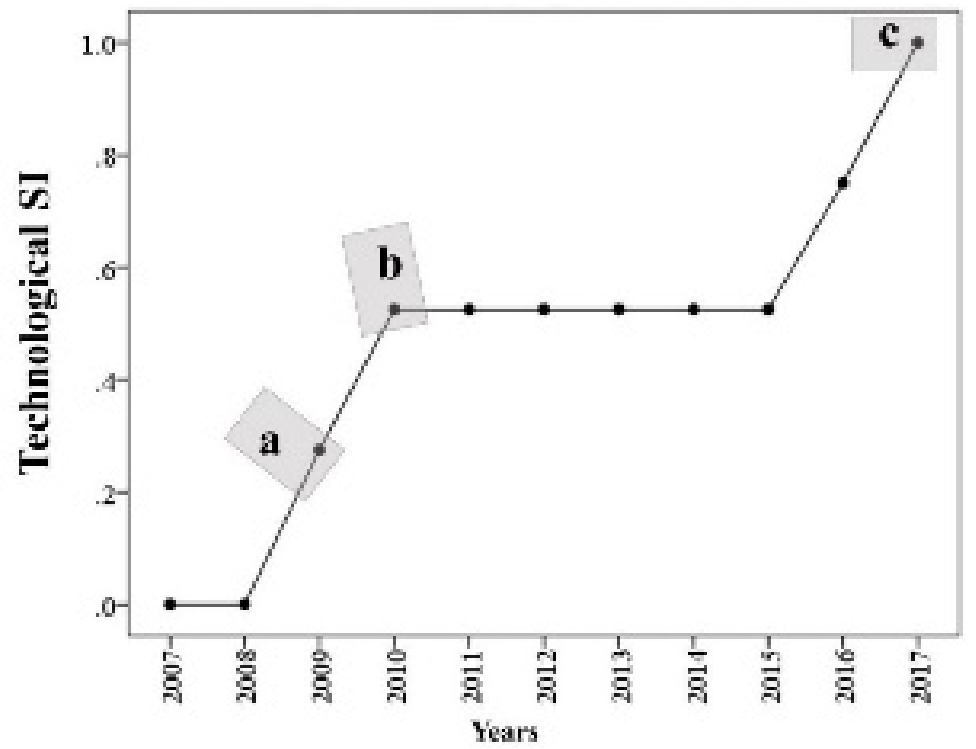

(a) Increase in the number of wastewater treatment plants and their capacity; (b) increase in the use of alternative energy; (c) implementation of surveillance camera. Source: authors' elaboration. 
Table 5.

Factor loadings of Principal Components $(P C)$ and determination coefficients $\left(R^{2}\right)$ for technological dimension in Loreto Bay National Park, Baja California Sur, México.

\begin{tabular}{|l|c|c|}
\hline \multirow{2}{*}{ Indicators } & Factor loadings & $\mathrm{R}^{2}$ \\
\hline Alternative energy in tourism companies & $\mathbf{C P 1}$ & \multicolumn{1}{l}{} \\
\hline Wastewater treatment plants & $\mathbf{. 9 4}$ & 0.631 \\
\hline Capacity of wastewater treatment plants & $\mathbf{. 9 7 0}$ & 0.941 \\
\hline Surveillance cameras & $\mathbf{. 9 6 9}$ & 0.940 \\
\hline
\end{tabular}

Factor loadings $>0.50$ were considered significant (in bold).

\subsection{General Sustainability Index (GSI)}

The GSI increased within the period of study after a decrease in 2008. However, it showed irregular variations that corresponded to IS of environmental and tourism dimensions (Figure 6).

Figure 6.

General Sustainability Index (GSI) trend, from 2007-2017.

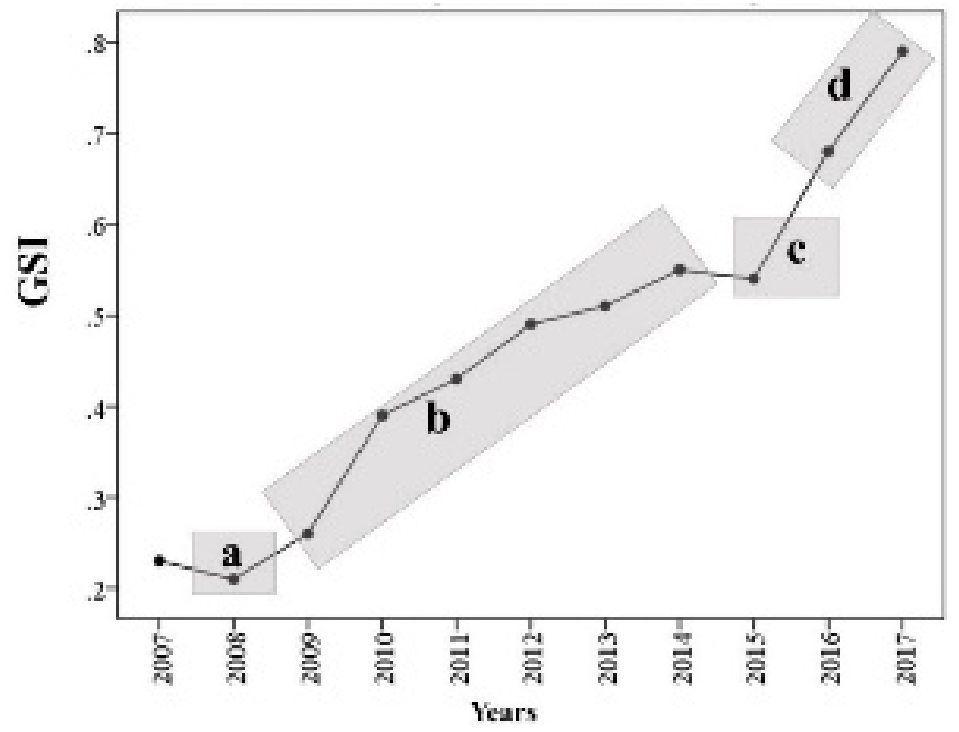

(a) Economic crisis; (b) irregular variations related to tourism and environmental SI; (c) decrease in environmental monitoring and budget allocated; (d) increase in monitoring, certification, tourism in Loreto Bay National Park (LBNP) and implementation of surveillance camera. Source: authors' elaboration. 
del Castillo Velasco Martínez, I.; Beltrán-Morales, L. F.; Avilés-Polanco, G.; Ibáñez-Pérez, R. M.; Arnaud-Franco, G. A.; Herrera-Ulloa, Á.; Ortega-Rubio, A.

Table 6.

Significant correlations $(p<0.05)$ between General Sustainability Index (GSI) and indicators of the four dimensions in Loreto Bay National Park, Baja California Sur, México.

\begin{tabular}{|c|c|c|}
\hline Dimension & Sustainability indicator & $\begin{array}{l}\text { Correlation } \\
\text { coefficient }\end{array}$ \\
\hline \multirow[t]{6}{*}{ Socio-economic } & Birthrate & -0.834 \\
\hline & Population growth & 0.921 \\
\hline & Literacy & 0.955 \\
\hline & Piped water & 0.890 \\
\hline & Homes without overcrowding & 0.909 \\
\hline & Locations with more than 5000 inhabitants & 0.938 \\
\hline \multirow[t]{5}{*}{ Tourism } & Tours to islands & 0.831 \\
\hline & Kayak services & 0.883 \\
\hline & Recreational diving & 0.743 \\
\hline & Resident Tourism Companies & 0.977 \\
\hline & Accommodation Offer & 0.970 \\
\hline \multirow[t]{3}{*}{ Environmental } & Urban solid waste generation & 0.626 \\
\hline & Recycling & 0.897 \\
\hline & Environmental certifications & 0.840 \\
\hline \multirow[t]{3}{*}{ Technological } & Alternative energy in tourism companies & 0.775 \\
\hline & Wastewater treatment plants & 0.858 \\
\hline & Capacity of wastewater treatment plants & 0.858 \\
\hline
\end{tabular}

\section{Discussion}

\subsection{Socioeconomic dimension}

The positive trend of socioeconomic indicators suggests an improvement in education, employment and housing, which agrees with the marginalization index categorized as very low for Loreto from 2000 to 2015 (CONAPO 2016). This parameter measures the lack of opportunities for development and progress of a social group or geographic area, which indicates that the population of Loreto has maintained a high level of well-being (Téllez Vázquez et al., 2016). In contrast, the town of Cabo Pulmo in Mexico, which houses a PA with the same name, lacks basic services such as drainage, roads in good condition, health and education; therefore, it has been classified with a high marginalization index (R. Ibáñez Pérez, 2015).

Infant mortality rate was used to assess the population health status (Reidpath \& Allotey, 2003) however, are more complex, and for resource poor countries, this added burden could mean diverting funds from much needed programmes. Unfortunately, the conjecture, that DALE is a better measure of 
population health than IMR, has not been empirically tested. Methods: IMR and DALE data for 1997 were obtained from the World Bank and the World Health Organisation, respectively, for 180 countries. Findings: There is a strong (generally. The positive trend of this indicator (given its standardization), evidenced a decrease in the number of deaths of children under one year of age from 2007-2017, which was consistent with the increase in population percentage with health insurance (from 75-88\%) from 2010-2015 (INEGI 2010; INEGI 2017).

Population growth showed a decrease during the period of study. This indicator has been considered as an economic growth factor (Peterson, 2017). However, in developing countries, such as Mexico, it could have a negative impact on sustainable development (Güney, 2017). Negative effects, both environmental and socioeconomic, are related to the increase in resource consumption, as observed in Nigeria, where the increase in population growth and birth rates have led to a rise in poverty, as well as an excessive use of natural resources (Ngoka, 2013).

The decrease in birth rate agreed with national values during the same period, which was due to implementing family planning programs and increasing the use of contraceptive methods (SS (Secretaría de Salud) 2015; INEGI 2017). In addition to a negative correlation with the GSI, birth rate showed an $\mathrm{R}^{2}$ of $80 \%$, which means that it had an important contribution in the SI. In Loreto, $80 \%$ of the population are native to the State of BCS, and at national level the state has one of the lowest emigration rates (Ganster et al. 2007; CONAPO 2015; Gordillo \& Plassot 2017). Therefore, the negative trend of population growth is mainly related to a decrease in birth rate.

\subsection{Tourism dimension}

One of the goals of sustainable tourism is to improve life quality of the host community (OMT 2005). The positive correlation between life quality and some tourism offer indicators represent a benefit to local community. Tourism benefits on the life quality of residents in BCS have been reflected in studies conducted with coastal communities that host a PA, such as El Vizcaíno Biosphere Reserve and Cabo Pulmo National Park. Regarding the first PA, visitors who take tours to Laguna Ojo de Liebre and Laguna de San Ignacio for whale-watching, generate an economic gain of approximately USD \$3 million dollars per season; which benefits the local community, mainly operators and tour guides (Brenner et al., 2016). Likewise, in the town of Cabo Pulmo, residents occupy $89 \%$ of the jobs within the tourism sector, which generate a socio-economic benefit (R. Ibáñez Pérez, 2015). In this study, the indicators that showed a positive correlation with residents' life quality were the number of companies that offer tourism services. This result was consistent with a study conducted about Loreto residents' perception where the results reflected that tourism provided benefits through direct and indirect employment generation (Mendoza Ontiveros \& González Sosa, 2014).

Tourism offer indicators showed a strong contribution to the SI, where more than $80 \%$ of its variance was explained by the index, thus assuming that these variables have contributed to the sustainable development of the site. The number of tourists visiting the LBNP was the only demand indicator with positive trend; these data are annual and come from the sale of bracelets through CONANP. Since 2014, each of the beaches, trails and dive sites within the LBNP have had their own established carrying capac- 
del Castillo Velasco Martínez, I.; Beltrán-Morales, L. F.; Avilés-Polanco, G.; Ibáñez-Pérez, R. M.; Arnaud-Franco, G. A.; Herrera-Ulloa, Á.; Ortega-Rubio, A.

ity (CONANP 2016). These data indicate the maximum number of people who can make use of the site without causing damage, so they represent a useful tool for management and conservation of the area, besides helping to identify the areas that need more attention (González-Guerrero et al., 2016; R. Ibáñez Pérez, 2016). The number of LBNP visitors suggests that carrying capacity has not exceeded; however, this registration is annual and does not specify the degree of visitation in each of the sites. An effective implementation of carrying capacity requires that political actors and responsible institutions perform the application of specific measures. Likewise, the value of carrying capacity should be made known to tour operators (Coccossis \& Mexa, 2002), so they can keep track of the number of visitors allowed.

The decrease in tourism influx in 2009 coincides with the global financial crisis in 2008 in the United States (Zurita González et al., 2009). However, one of the main factors that influence low tourism influx is destination location (De Sicilia Muñoz, 2000). Loreto is located within the same federal entity as Los Cabos, one of the main tourist destinations at international level (SECTUR et al. 2014), which has a greater offer of services and air connectivity (R. Ibáñez Pérez et al., 2016). In contrast, access to Loreto is hindered by the low flight supply (Mendoza Ontiveros \& González Sosa, 2014). The economic benefits of tourism have been evident and reported in resident perception studies (Andereck et al., 2005; Ávila Foucat, 2002; Rivera \& Lee, 2016; Sharpley, 2014)but few cases have shown this to be sustainable. This paper assesses the sustainability of the Ventanilla community-based ecotourism management (CBEM, confirming the need to increase tourism demand. However, uncontrolled growth in the number of visitors, poor vigilance and deficiency in legislation application may generate damages for the environment and resident population (Buckley, 2011; Chávez Ramírez \& de la Cueva Salcedo, 2010; Eagles et al., 2002; Monz et al., 2013). Such is the case of the municipality of Los Cabos in Mexico, whose growth in tourism development has generated several problems, such as vehicle traffic, water scarcity, deficiency in solid waste disposal, pollution of natural areas, loss of traditional activities, as well as economic growth oriented towards investors and not residents (Montaño et al., 2016). On the other hand, low tourism influx, and therefore moderate tourism development, may generate advantages, such as greater security, less pollution and agglomeration, as well as less poverty (Almeida García et al., 2015; Andereck et al., 2005)

\subsection{Environmental dimension}

Due to lack of data, the information on environmental indicators was obtained from different public and civil organization sources. These institutions differ in their collection method of data, organization, and publication period, which could affect trend and variation. The scarce information on environmental indicators has been previously reported in a sustainability study in BCS (Herrera-Ulloa et al., 2003).

According to the perception of hotel managers in London and other tourism enterprises in West of England, environment certifications offer advantages, such as providing information about the implementation of sustainability practices, cost-savings by implementing these practices, increasing company competitiveness as tourists become more aware of the environment, and reducing environmental impacts (Geerts, 2014; Jarvis et al., 2010). Although this indicator showed a positive trend and a high contribution to the SI, none of these certifications were obtained by hotels or tour operators. 
The generation of urban solid waste (USW) has a negative relationship with sustainability; pollutants that occur in dumps could cause environmental and aesthetic damages, which may affect the image of a tourist destination (Kiss Köfalusi \& Encarnación Aguilar, 2006). This problem has been observed in some PA with tourism activity, such as Parque Estatal El Ocotal and Parque de los Venados, in the State of Mexico, where solid waste generation and dispersion was one of the main environmental damages (Pérez Ramírez et al., 2009). Therefore, the positive correlation of this indicator with the GSI indicates the decrease in USW generation in Loreto, which is related to an increase in sustainability.

The amount of waste received for recycling is a management indicator. A positive trend and correlation with the GSI indicate that an increase in the amount of waste received by collection centers is related to a rise in sustainability. According to SEMARNAT et al. (2013), 34\% of USW generated in Loreto was recyclable waste, while $41 \%$ could have been used for composting. Therefore, if the disposal of recyclable waste increased in collection centers, the amount of USW would decrease by more than $50 \%$.

Responsible institutions for conducting surveillance and detecting illegal actions in the LBNP are CONANP and PROFEPA; therefore, if surveillance decreases, the record of illegal actions also decreases, which agrees with a study conducted in the Kakum National Park in Ghana where the increase in patrol efforts was found related to an increase in detecting illegal wildlife capture and hunting. This result was due to a reduced surveillance period, as well as the distance traveled (Wiafe, 2016). Therefore, as indicated by Miller et al. (2013)control and surveillance (MCS, monitoring and surveillance activities are necessary tools to detect and prevent illicit actions.

\subsection{Technological dimension}

Records indicated that the number of tourists, lodging units, and tourism companies have increased in the last two years of the study period, which suggests a possible increase in water consumption and subsequent competition for resources with residents (Mendoza Ontiveros \& González Sosa, 2014). Therefore, an efficient wastewater treatment allows a percentage of water to be reused, reducing the consumption rate and environmental impacts that could be generated by treated water disposal at sea (Gössling et al., 2012)direct tourism-related water use is considerably less than $1 \%$ of global consumption, and will not become significant even if the sector continues to grow at anticipated rates of around $4 \%$ per year (international tourist arrivals. The increase in number and capacity of wastewater treatment plants suggested that despite the possible increase in consumption, the amount of water being treated and reused was greater.

In Loreto, technological innovation within the tourism sector is deficient, mainly that related to alternative energy. This municipality has important sources of renewable energy, such as solar radiation and wind; however, as observed in the results, its use is still limited. Generally, this situation might be due to the lack of knowledge about the advantages of this type of energy, as it has occurred in other regions of the country, such as in the Caribbean (Breceda et al., 2007; Schlüter, 1996). The economic benefits provided by renewable energy in the medium and long term are greater, such as a decrease in costs and the possibility of generating a self-sufficient system (Jiménez Castilla, 2014; 
del Castillo Velasco Martínez, I.; Beltrán-Morales, L. F.; Avilés-Polanco, G.; Ibáñez-Pérez, R. M.; Arnaud-Franco, G. A.; Herrera-Ulloa, Á.; Ortega-Rubio, A.

Schlüter, 1996). In addition, it is also an indicator of good sustainable practices and one of the standards for obtaining environmental certifications, which could help generate greater competitiveness (EarthCheck, 2018; Jarvis et al., 2010).

An essential component for a PA management with tourism is the continuous monitoring of visitors. Surveillance actions and the number of staff needed may require a high cost, especially if it is a Marine Protected Area (Leung et al., 2015). According to CONANP the same year that a surveillance camera was installed in Loreto port, the number of illegal actions increased, mainly those related to fishing and tourism (Pronatura, 2018), which indicated that the application of this instrument was successful. Other studies have used aerial vehicles with the same surveillance function in a Marine Protected Area; this technology offers advantages, such as a decrease in fuel consumption and working hours during patrols (Arefin, 2018).

\section{Recommendations}

The study has shown LBNP sustainability, and its areas of influence increased from 2007-2017. Although the SI reflected a positive trend in all dimensions, the socioeconomic one showed the least variation. To continue generating socio-economic benefits to the local community, governmental agencies and civil organizations should support and work jointly with local businesses.

Irregular variations in tourism SI are mainly due to demand indicators. To increase tourist influx and hotel occupancy, efforts should be focused towards promotion and connectivity of the tourist destination - the latter through the increase in flight offer. Nevertheless, tourism demand may also generate costs, which should be considered and prevented. Control over the number of visitors to LBNP is greatly important and could be achieved through constant communication with tour operators, as well as by recording visitation at each of the sites in the area, avoiding in this manner exceeding carrying capacity.

Certification number was the environmental indicator with the greatest contribution to the SI, as well as a high correlation with GSI. Therefore, hotel and tour operators should be encouraged to obtain environmental certifications. Generation and management of USW showed positive results; however, it is necessary to continue promoting USW sustainable management, including responsible disposal, reduction in waste generation and recycling. In future studies, the indicators that reflect the state of the system should be implemented, such as sea water quality on beaches, emission of greenhouse gases, as well as energy and drinking water consumption. Besides surveillance cameras, another technological indicator that should be promoted in Loreto is renewable energy use by hotels and tour operators. This decision would be reflected in a decrease in environmental impact indicators, such as the consumption of electrical energy and greenhouse gases emissions.

One of main obstacles during this study was information availability at municipal level and even more at PA level. Therefore, in future studies the use of indicators, such as those discussed here, should be a guide to modify them accordingly to the study area and data availability. 


\section{Conclusion}

This study represents a novel approach to evaluate the performance of nature-based tourism sustainability in a PA using indicators. Its main contributions are discussed next. First, most works about tourism sustainability have focused on determining the system state at a certain time; however, the process by which a level was reached is unknown. In this study, the data came from economic censuses or environmental monitoring carried out within a period of time, and the trend of indicators and indexes was known; in this manner, success stories may be detected, as well as main issues where efforts should be focused. A second contribution of the method was data standardization, which allowed comparing indicators with different measurement units. In addition, establishing maximum and minimum values was not required, which are generally not available locally. Third, this study considered indicators of the three pillars of sustainability (social, economic, and environmental) besides tourism and technological dimensions; therefore, the model covered topics of all dimensions that influence sustainable tourism development. Finally, the method measured with statistical significance the contribution degree of the indicators to SI by using a PCA. Therefore, this instrument can be used to evaluate PA management with visitors and assist in decision-making.

\section{Acknowledgments}

This study was funded by Centro de Investigaciones Biológicas del Noroeste S.C. (CIBNOR, PPAC). The authors thank Eco-Alianza de Loreto A.C., administrative and operational staff of the Loreto Bay National Park; tourism companies of Loreto for their willingness, support and providing valuable information for the development of this study and Diana Fischer for editorial services.

\section{Funding}

This study was supported by Centro de Investigaciones Biológicas del Noroeste S.C. (CIBNOR, PPAC).

\section{Declaration of data availability}

The data used to report the research results are available and can be accessed by requesting them to the email idelcastillo@pg.cibnor.mx. 
del Castillo Velasco Martínez, I.; Beltrán-Morales, L. F.; Avilés-Polanco, G.; Ibáñez-Pérez, R. M.; Arnaud-Franco, G. A.; Herrera-Ulloa, Á.; Ortega-Rubio, A.

\section{References}

Almeida García, F., Balbuena Vázquez,A., \& Cortés Macías, R. (2015). Resident's attitudes towards the impacts of tourism. Tourism Management Perspectives, 13, 33-40. https://doi.org/10.1016/J.TMP.2014.11.002

Anand, S., \& Sen, A. K. (1994). Human Development Index: Methodology and Measurement.

Andereck, K. L., Valentine, K. M., Knopf, R. C., \& Vogt, C. A. (2005). Residents' perceptions of community tourism impacts. Annals of Tourism Research, 32(4), 1056-1076. https://doi.org/10.1016/J.ANNALS.2005.03.001

Arefin, A. M. E. (2018). Proposal of a marine protected area surveillance system against illegal vessels using image sensing and image processing. Acta Ecologica Sinica, 38(2), 111-116. https://doi.org/10.1016/J.CHNAES.2017.06.015

Ashok, S., Tewari, H. R., Behera, M. D., \& Majumdar, A. (2017). Development of ecotourism sustainability assessment framework employing Delphi, C\&I and participatory methods: A case study of KBR, West Sikkim, India. Tourism Management Perspectives, 21, 24-41. https://doi.org/10.1016/J.TMP.2016.10.005

Asmelash, A. G., \& Kumar, S. (2019). Assessing progress of tourism sustainability: Developing and validating sustainability indicators. Tourism Management, 71, 67-83. https://doi.org/10.1016/J.TOURMAN.2018.09.020

Astier, M., Masera, O. R., \& Galván-Miyoshi, Y. (2008). Evaluación de sustentabilidad. Un enfoque dinámico y multidimensional.

Ávila Foucat, V. S. (2002). Community-based ecotourism management moving towards sustainability, in Ventanilla, Oaxaca, Mexico. Ocean \& Coastal Management, 45, 511-529.

Balmford, A., Beresford, J., Green, J., Naidoo, R., Walpole, M., \& Manica, A. (2009). A Global Perspective on Trends in Nature-Based Tourism. PLoS Biology, 7(6), 1-6. https://doi.org/10.1371/journal.pbio.1000144

Balmford, A., Green, J. M. H., Anderson, M., Beresford, J., Huang, C., Naidoo, R., Walpole, M., \& Manica, A. (2015). Walk on the Wild Side: Estimating the Global Magnitude of Visits to Protected Areas. PLOS Biology, 13(2), e1002074. https://doi.org/10.1371/journal.pbio.1002074

Blancas, F. J., Lozano-Oyola, M., González, M., \& Caballero, R. (2016). Sustainable tourism composite indicators: a dynamic evaluation to manage changes in sustainability. Journal of Sustainable Tourism, 24(10), 1403-1424. https://doi.org/10.1080/09669582.2015.1122014

Breceda, M., Rincón, E., \& Santander, L. C. (2007). Uso de energía alternativa en los desarrollos turísticos del Caribe. Teoría y Práxis, 3, 161-171.

Brenner, L., Mayer, M., \& Stadler, C. (2016). The economic benefits of whale watching in El Vizcaíno Biosphere Reserve, Mexico. Economía Sociedad y Territorio, 16(51), 429-457. https://doi.org/10.22136/est002016637

Buckley, R. (2011). Tourism and environment. Annual Review of Environment and Resources, 36, 397416. https://doi.org/10.1146/annurev-environ-041210-132637 
Cabezas, H., Pawlowski, C. W., Mayer, A. L., \& Hoagland, N. T. (2003). Sustainability: ecological, social, economic, technological, and systems perspectives. Clean Technologies and Environmental Policy, 5, 167-180. https://doi.org/10.1007/s10098-003-0214-y

Castellani, V., \& Sala, S. (2010). Sustainable performance index for tourism policy development. Tourism Management, 31(6), 871-880. https://doi.org/10.1016/J.TOURMAN.2009.10.001

Chávez Ramírez, R., \& de la Cueva Salcedo, H. (2010). Un Estudio Comparativo del Mercado de Observación de Ballenas en México A Comparative Study of the Whale-Watching Market in Mexico. Panorama Socioeconómico, 28(40), 72-89.

Choi, H. C., \& Sirakaya, E. (2006). Sustainability indicators for managing community tourism. Tourism Management, 27(6), 1274-1289. https://doi.org/10.1016/J.TOURMAN.2005.05.018

CNET (Consejo Nacional Empresarial Turístico). (2018). Panorama de la Actividad Turística en México. Universidad Anáhuac México, 24.

Coccossis, H., \& Mexa, A. (2002). Defining, measuring and evaluating carrying capacity in European tourism destinations.

CONANP (Comisión Nacional de Áreas Naturales Protegidas). (2016). Fichas de evaluación ecológica de áreas naturales protegidas del noroeste de México. Parque Nacional Bahía de Loreto.

CONANP (Comisión Nacional de Áreas Naturales Protegidas). (2018). Marco Estratégico de Turismo Sustentable en Áreas Naturales Protegidas de México. Secretaría de Medio Ambiente y Recursos Naturales.

CONANP (Comisión Nacional de Áreas Naturales Protegidas), \& SEMARNAT (Secretaría del Medio Ambiente y Recursos Naturales). (2007). Programa de Turismo en Áreas Protegidas 2006-2012.

CONANP [Comisión Nacional de Áreas Naturales Protegidas]. (2002). Programa de Manejo Parque Nacional Bahía de Loreto, México (Segunda ed).

CONAPO (Consejo Nacional de Población). (2015). Datos abiertos del índice de marginación. http://www.conapo.gob.mx/es/CONAPO/Datos_Abiertos_del_Indice_de_Marginacion

CONAPO (Consejo Nacional de Población). (2016). Índice de marginación por municipio 1990-2015. Datos Abiertos Del Índice de Marginación. http://www.conapo.gob.mx/es/CONAPO/Datos_Abiertos_del_Indice_de_Marginacion

Copus, A. K., \& Crabtree, J. R. (1996). Indicators of socio-economic sustainability: An application to remote rural Scotland. Journal of Rural Studies, 12(1), 41-54. https://doi.org/10.1016/0743-0167(95)00050-X

Daniel, W. W. (2008). Bioestadística : base para el análisis de las ciencias de la salud(Cuarta). Limusa Wiley.

De Sicilia Muñoz, R. A. (2000). El corredor turístico Loreto-Nopoló-Puerto Escondido, Baja California Sur, en el contexto de los Centros Integralmente Planeados. Cuadernos de Turismo, 5, 53-68.

DOF [Diario Oficial de laFederación]. (2019). Programa de Manejo del Parque Nacional Bahía de Loreto.

Dormann, C. F., Elith, J., Bacher, S., Buchmann, C., Carl, G., Carré, G., Marquéz, J. R. G., Gruber, B., Lafourcade, B., Leitão, P. J., Münkemüller, T., McClean, C., Osborne, P. E., Reineking, B., 
del Castillo Velasco Martínez, I.; Beltrán-Morales, L. F.; Avilés-Polanco, G.; Ibáñez-Pérez, R. M.; Arnaud-Franco, G. A.; Herrera-Ulloa, Á.; Ortega-Rubio, A.

Schröder, B., Skidmore, A. K., Zurell, D., \& Lautenbach, S. (2013). Collinearity: a review of methods to deal with it and a simulation study evaluating their performance. Ecography, 36(1), 27-46. https://doi.org/10.1111/j.1600-0587.2012.07348.x

Dwyer, L., \& Edwards, D. (2000). Nature-based tourism on the edge of urban development. Journal of Sustainable Tourism, 8(4), 267-287. https://doi.org/10.1080/09669580008667364

Eagles, P. F. J. (2014). Research priorities in park tourism. Journal of Sustainable Tourism, 22(4), 528549. https://doi.org/10.1080/09669582.2013.785554

Eagles, P. F. J., Mccool, S. F., \& Haynes, C. D. (2002). Sustainable Tourism in Protected Areas Guidelines for Planning and Management. IUCN Gland.

EarthCheck. (2018). Acerca de. https://es.earthcheck.org/acerca-de/

Gan, X., Fernandez, I. C., Guo, J., Wilson, M., Zhao, Y., Zhou, B., \& Wu, J. (2017). When to use what: Methods for weighting and aggregating sustainability indicators. Ecological Indicators, 81, 491502. https://doi.org/10.1016/j.ecolind.2017.05.068

Ganster, P., Arizpe, O., \& Ivanova, A. (Eds.). (2007). Loreto: The future of the First Capital of the Californias. San Diego State University Press.

GBCS (Gobierno de Baja California Sur). (2018). Loreto. Información Estratégica.

Geerts, W. (2014). Environmental certification schemes: HOTEL managers' views and perceptions. International Journal of Hospitality Management, 39, 87-96. https://doi.org/10.1016/j.ijhm.2014.02.007

González-Guerrero, G., Olivares Robles, A. K., Valdez Pérez, M. E., Morales Ibarra, R., \& Castañeda Martínez, T. (2016). The Application of the Tourist Carrying Capacity Technique and its Critical Analysis for Tourism Planning. Tourism Planning \& Development, 13(1), $72-87$. https://doi.org/10.1080/21568316.2015.1076512

Gordillo, G., \& Plassot, T. (2017). Migraciones internas: un análisis espacio-temporal del periodo 19702015. Journal of Economic Literature, 14(40), 67-100.

Gössling, S., Peeters, P., Hall, C. M., Ceron, J. P., Dubois, G., Lehmann, L. V., \& Scott, D. (2012). Tourism and water use: Supply, demand, and security. An international review. In Tourism Management (Vol. 33, Issue 1, pp. 1-15). https://doi.org/10.1016/j.tourman.2011.03.015

Guerrero de Lizardi, C. (2008). Introducción a la econometría aplicada. Trillas.

Gujarati, D. N., \& Porter, D. C. (2010). Essentials of Econometrics (Cuarta). Mc Graw Hill. https://doi.org/10.1016/S0095-0696(02)00054-2

Güney, T. (2017). Population growth and sustainable development in developed-developing countries: An IV (2SLS) approach. The Journal Of Faculty Of Economics and Administrative Sciences, 22(4), 1255-1277.

Hashemkhani Zolfani, S., Sedaghat, M., Maknoon, R., \& Zavadskas, E. K. (2015). Sustainable tourism: a comprehensive literature review on frameworks and applications. Economic Research-Ekonomska Istraživanja, 28(1), 1-30. https://doi.org/10.1080/1331677X.2014.995895 
Hernández Trejo, V., Urciaga García, J., Hernández Vincent, M., \& Palos Arocha, L. (2009). Valoración económica del Parque Nacional Bahía de Loreto a través de los servicios de recreación de pesca deportiva. Región y Sociedad, 21(44), 195-223.

Herrera-Ulloa, Á., Charles, A. T., Lluch-Cota, S. E., Ramirez-Aguirre, H., Hernández-Váquez, S., \& Ortega-Rubio, A. (2003). A regional-scale sustainable development index: the case of Baja California Sur, Mexico. International Journal of Sustainable Development \& World Ecology, 10(4), 353-360.

Ibáñez Pérez, R. (2015). Medición de la Sustentabilidad Turística en una Área Natural Protegida del Noroeste de México. Áreas Naturales Protegidas Scripta, 1(1), 9-34. https://doi.org/10.18242/ANPScripta.2015.01.01.01.0001

Ibáñez Pérez, R. (2016). Capacidad de carga turística como base para el manejo sustentable de actividades ecoturísticas en Unidades de Manejo Ambiental (UMA) de Baja California Sur (BCS). El Periplo Sustentable, 0(30), 38-76.

Ibáñez Pérez, R., Cruz Chávez, P., \& Juárez Mancilla, J. (2016). Perfil y satisfacción del visitante del destino: Los Cabos, Baja California Sur. Opción, 32(13), 1041-1068.

Ibáñez Pérez, R. M. (2014). Turismo y Sustentabilidad en Pequeñas Localidades Costeras de Baja California Sur (BCS). El Periplo Sustentable, 0(26), 67-101.

INEGI (Instituto Nacional de Estadística y Geografía). (2010). Anuario estadístico de Baja California Sur 2010.

INEGI (Instituto Nacional de Estadística y Geografía). (2016). Anuario estadístico y geográfico de Baja California Sur 2016.

INEGI (Instituto Nacional de Estadística y Geografía). (2017a). Anuario Estadístico y Geográfico de Baja California Sur 2017. https://doi.org/10.7283/T5MW2F2D

INEGI (Instituto Nacional de Estadística y Geografía). (2017b). INEGI Estadísticas de Natalidad. https://www.inegi.org.mx/app/areasgeograficas/?ag=03\#tabMCcollapse-Indicadores

INEGI (Instituto Nacional de Estadística y Geografía), \& INE (Instituto Nacional de Ecología). (2000). Indicadores de Desarrollo Sustentable en México.

Jarvis, N., Weeden, C., \& Simcock, N. (2010). The benefits and challenges of sustainable tourism certification: A case study of the green tourism business scheme in the West of England. Journal of Hospitality and Tourism Management, 17(1), 83-93. https://doi.org/10.1375/jhtm.17.1.83

Jiménez Castilla, T. (2014). Energías renovables y turismo comunitario: una apuesta conjunta para el desarrollo humano sostenible de las comunidades rurales. Energética, 44, 93-105. https://doi.org/10.15446/energetica

Jones, N., McGinlay, J., \& Dimitrakopoulos, P. G. (2017). Improving social impact assessment of protected areas: A review of the literature and directions for future research. In Environmental Impact Assessment Review (Vol. 64, pp. 1-7). Elsevier Inc. https://doi.org/10.1016/j.eiar.2016.12.007 
del Castillo Velasco Martínez, I.; Beltrán-Morales, L. F.; Avilés-Polanco, G.; Ibáñez-Pérez, R. M.; Arnaud-Franco, G. A.; Herrera-Ulloa, Á.; Ortega-Rubio, A.

Kim, Y., Kim, C. ki, Lee, D. K., Lee, H. woo, \& Andrada, R. I. T. (2019). Quantifying nature-based tourism in protected areas in developing countries by using social big data. Tourism Management, 72 , 249-256. https://doi.org/10.1016/j.tourman.2018.12.005

Kiss Köfalusi, G., \& Encarnación Aguilar, G. (2006). Los productos y los impactos de la descomposición de residuos sólidos urbanos en los sitios de disposición final. Gaceta Ecológica, 79, 39-51.

Leung, Y.-F., Spenceley, A., Hvenegaard, G., \& Buckley, R. (2015). Tourism and Visitor Management in Protected Areas Guidelines for sustainability. Best Practice Protected Area Guidelines Series No. XX.

Li, W. (2004). Environmental management indicators for ecotourism in China's nature reserves: A case study in Tianmushan Nature Reserve. Tourism Management, 25(5), 559-564. https://doi.org/10.1016/J.TOURMAN.2003.06.001

Mayer, A. L. (2008). Strengths and weaknesses of common sustainability indices for multidimensional systems. Environment International, 34(2), 277-291. https://doi.org/10.1016/J.ENVINT.2007.09.004

Mendoza Ontiveros, M. M., \& González Sosa, J. C. (2014). Impactos socioculturales del turismo en el Centro Integralmente Planeado Loreto, Baja California Sur, México. Percepción de los residentes locales. Teoría y Praxis, 16, 117-146.

Miller, D. G. M., Slicer, N. M., \& Hanich, Q. (2013). Monitoring, control and surveillance of protected areas and specially managed areas in the marine domain. Marine Policy, 39, 64-71. https://doi.org/10.1016/J.MARPOL.2012.10.004

Montaño, A., Ivanova, A., Martinez, G., \& Pérez, J. (2016). Tourism and sustainable local development in the city of Cabo San Lucas, Mexico 1990-2015. 11 International Conference Th on Urban Regeneration and Sustainability, 725-734. https://doi.org/10.2495/SC160601

Monz, C. A., Pickering, C. M., \& Hadwen, W. L. (2013). Recent advances in recreation ecology and the implications of different relationships between recreation use and ecological impacts. Frontiers in Ecology and the Environment, 11(8), 441-446. https://doi.org/10.1890/120358

Nardo, M., \& Saisana, M. (2005). OECD/JRC Handbook on constructing composite indicators. Putting theory into practice.

Ngoka, P. (2013). Population, development and the environment-issue in sustainable ecotourism Nigeria. International Journal of Innovations in Environmental Science and Technology, 3(2), 1-13.

OMT (Organización Mundial del Turismo). (2005). Indicadores de desarrollo sostenible para los destinos turísticos: Guía práctica.

OMT (Organización Mundial del Turismo). (2012). Turismo y sostenibilidad.

OMT (Organización Mundial del Turismo). (2018). Panorama OMT del turismo internacional. Edición 2018. (Primera ed).

Pérez Ramírez, C., Zizumbo Villarreal, L., \& González Vera, M. (2009). Impacto ambiental del turismo en áreas naturales protegidas; procedimiento metodológico para el análisis en el Parque Estatal El Ocotal, México. El Periplo Sustentable, 16, 25. https://doi.org/10.21854/eps.v0i16.921 
Peterson, E. W. F. (2017). The Role of Population in Economic Growth. SAGE Open, 7(4), 1-15. https://doi.org/10.1177/2158244017736094

Pronatura. (2018). Se fortalece Inspección y Vigilancia en el Parque Nacional Bahía de Loreto. http:/pronatura-noroeste.org/camara-de-vigilancia-en-el-parque-nacional-bahia-de-loreto/

Reidpath, D. D., \& Allotey, P. (2003). Infant mortality rate as an indicator of population health. J Epidemiol Community Health, 57, 344-346. https://doi.org/10.1136/jech.57.5.344

Rivera, M., \& Lee, S. H. (2016). Tourism development and happiness: A residents' perspective. Journal of Destination Marketing \& Management, 5(1), 5-15. https://doi.org/10.1016/J.JDMM.2015.04.002

Saisana, M., \& Tarantola, S. (2002). State-of-the-art Report on Current Methodologies and Practices for Composite Indicator Development. https://doi.org/10.13140/RG.2.1.1505.1762

Santana-Medina, N., Franco-Maass, S., Sánchez-Vera, E., Imbernon, J., \& Nava-Bernal, G. (2013). Participatory generation of sustainability indicators in a natural protected area of Mexico. Ecological Indicators, 25, 1-9. https://doi.org/10.1016/J.ECOLIND.2012.09.002

Schlüter, R. G. (1996). Energía renovable y turismo en la Patagonia Argentina. Estudios y Perspectivas En Turismo, 5, 52-71.

Schuschny, A., \& Soto, H. (2009). Guía metodológica Diseño de indicadores compuestos de desarrollo sostenible.

SECTUR (Secretaría de Turismo), GBCS (Gobierno de Baja California Sur), FONATUR (Fondo Nacional de Fomento al Turismo), \& UABCS (Universidad Autónoma de Baja California Sur). (2014). Agendas de Competitividad de los destinos turísticos de México. Los Cabos Baja California Sur.

SEMARNAT (Secretaría de Medio Ambiente y Recursos Naturales), GBCS (Gobierno de Baja California Sur), \& Loreto, G. M. de. (2013). Programa Municipal para la Prevención y Gestión Integral de Residuos Sólidos del Municipio de Loreto, Baja California Sur.

Sharpley, R. (2014). Host perceptions of tourism: A review of the research. Tourism Management, 42, 37-49. https://doi.org/10.1016/J.TOURMAN.2013.10.007

Siikamäki, P., Kangas, K., Paasivaara, A., \& Schroderus, S. (2015). Biodiversity attracts visitors to national parks. Biodiversity and Conservation, 24(10), 2521-2534. https://doi.org/10.1007/s10531-015-0941-5

Singh, R. K., Murty, H. R., Gupta, S. K., \& Dikshit, A. K. (2009). An overview of sustainability assessment methodologies. Ecological Indicators, 9(2), 189-212. https://doi.org/10.1016/j.ecolind.2008.05.011

Snyman, S., \& Bricker, K. S. (2019). Living on the edge: benefit-sharing from protected area tourism. Journal of Sustainable Tourism, 27(6), 705-719. https://doi.org/10.1080/09669582.2019.1615496

SS (Secretaría de Salud). (2015). Boletín de Información Estadística 2014-2015.

Stronza, A., Gordillo, J., \& Amazonas, P. (2008). Community views of ecotourism. Pergamon, 35(2), $448-468$.

Tanguay, G. A., Rajaonson, J., \& Therrien, M. C. (2013). Sustainable tourism indicators: Selection criteria for policy implementation and scientific recognition. Journal of Sustainable Tourism, 21(6), 862-879. https://doi.org/10.1080/09669582.2012.742531 
del Castillo Velasco Martínez, I.; Beltrán-Morales, L. F.; Avilés-Polanco, G.; Ibáñez-Pérez, R. M.; Arnaud-Franco, G. A.; Herrera-Ulloa, Á.; Ortega-Rubio, A.

Téllez Vázquez, Y., Almejo Hernández, R., Raziel Hernández Álvarez, A., \& Romo Viramontes, R. (2016). Índice de marginación por entidad federativa y municipio 2015 (Primera ed). CONAPO.

Torres-Delgado, A., \& Saarinen, J. (2013). Using indicators to assess sustainable tourism development: a review. Tourism Geographies, 16(1), 31-47. https://doi.org/10.1080/14616688.2013.867530

Tsaur, S.-H., Lin, Y.-C., \& Lin, J.-H. (2006). Evaluating ecotourism sustainability from the integrated perspective of resource, community and tourism. Tourism Management, 27(4), 640-653. https://doi.org/10.1016/J.TOURMAN.2005.02.006

UNWTO (United Nations Environment Programme and World Tourism Organization). (2012). Tourism in the Green Economy Background Report. https://doi.org/10.18111/9789284414529

Wiafe, E. D. (2016). Wildlife laws monitoring as an adaptive management tool in protected area management in Ghana: a case of Kakum Conservation Area. SpringerPlus, 5(1). https://doi.org/10.1186/s40064-016-3129-x

Winter, P. L., Selin, S., Cerveny, L., \& Bricker, K. (2020). Outdoor recreation, nature-based tourism, and sustainability. Sustainability (Switzerland), 12(1), 1-12. https://doi.org/10.3390/SU12010081

WTO(World Tourism Organization). (2004). Indicators of Sustainable Development for Tourism Destinations A Guidebook.

WTO (World Tourism Organization). (2011). Technology in tourism.

Xin, T. K., \& Chan, J. K. L. (2014). Tour Operator Perspectives on Responsible Tourism Indicators of Kinabalu National Park, Sabah. Procedia -Social and Behavioral Sciences, 144, 25-34.

Zurita González, J., Martínez Pérez, J. F., \& Rodríguez Montoya, F. (2009). La crisis financiera y económica del 2008. Origen y consecuencias en los Estados Unidos y México. El Cotidiano, 157, 17-27. 


\section{Appendix.}

Table 7.

Significant correlation coefficients $(p>0.05)$ between indicators in Loreto Bay National Park.

\begin{tabular}{|c|c|c|c|c|c|c|c|c|c|c|c|c|c|c|c|c|c|c|c|c|}
\hline & $\mathrm{S} 1$ & $\mathrm{~S} 2$ & S3 & $\mathrm{S} 4$ & S5 & S6 & S7 & $\mathrm{T} 1$ & $\mathrm{~T} 2$ & T3 & $\mathrm{T} 4$ & T5 & T6 & $\mathrm{T} 7$ & $\mathrm{~T} 8$ & A1 & $\mathrm{A} 2$ & A5 & TC1 & TC2 \\
\hline S3 & -.86 & & & & & & & & & & & & & & & & & & & \\
\hline $\mathrm{S} 4$ & -.79 & & .96 & & & & & & & & & & & & & & & & & \\
\hline S5 & -.91 & & .96 & .90 & & & & & & & & & & & & & & & & \\
\hline S6 & -.81 & & .97 & .98 & .94 & & & & & & & & & & & & & & & \\
\hline S7 & -.75 & & .79 & .86 & .73 & .77 & & & & & & & & & & & & & & \\
\hline $\mathrm{T} 1$ & -.80 & -.66 & .83 & .82 & .83 & .82 & .71 & & & & & & & & & & & & & \\
\hline $\mathrm{T} 2$ & -.87 & & .93 & .89 & .92 & .90 & .73 & .92 & & & & & & & & & & & & \\
\hline $\mathrm{T} 3$ & & -.77 & .63 & .67 & .63 & .63 & .65 & .86 & .72 & & & & & & & & & & & \\
\hline $\mathrm{T} 4$ & -.87 & & .91 & .93 & .89 & .88 & .94 & .84 & .88 & .74 & & & & & & & & & & \\
\hline T6 & & & & & & & & & & & & .69 & & & & & & & & \\
\hline $\mathrm{T} 7$ & & & & & & & & & & & & & .72 & & & & & & & \\
\hline $\mathrm{T} 8$ & -.84 & & .94 & .94 & .91 & .91 & .90 & .84 & .89 & .71 & .97 & & & & & & & & & \\
\hline A1 & & & & & & & .75 & & & & .67 & & & & & & & & & \\
\hline $\mathrm{A} 2$ & -.90 & & .89 & .88 & .90 & .88 & .85 & .72 & .83 & & .91 & & & & .92 & & & & & \\
\hline A3 & & & & & & & & & & & & & & -.70 & & & & & & \\
\hline A4 & & & -.74 & -.67 & -.73 & -.70 & & -.82 & -.77 & -.61 & -.62 & & & & -.72 & & & & & \\
\hline A5 & -.65 & -.60 & .72 & .77 & .68 & .69 & .88 & .68 & .65 & .77 & .89 & & & & .84 & .70 & .71 & & & \\
\hline A6 & & & & & & & & & & & & & -.66 & & & & & & & \\
\hline TC1 & & & .69 & .71 & & .61 & .77 & .71 & .70 & .78 & .79 & -.78 & & & .78 & .85 & & .82 & & \\
\hline TC2 & & -.65 & .68 & .81 & .62 & .71 & .86 & .71 & .69 & .72 & .83 & & & & .82 & & .72 & .78 & .67 & \\
\hline TC3 & & -.65 & .68 & .81 & .62 & .71 & .86 & .71 & .69 & .72 & .83 & & & & .82 & & .72 & .78 & .67 & 1 \\
\hline
\end{tabular}

Birthrate (S1); population growth (S2); working population (S3); literacy (S4); piped water (S5); homes without overcrowding (S6); locations with more than 5000 inhabitants (S7); tours to islands (T1); kayak services (T2); recreational diving (T3); resident tourism companies (T4); hotel occupation (T5); influx of national tourists (T6); inflow of foreign tourists (T7); accommodation offer (T8); urban solid waste generation (A1); recycling (A2); surveillance (A3); environmental inspections (A4); environmental certifications (A5); budget (A6); alternative energy in tourism companies (TC1); wastewater treatment plants (TC2); capacity of wastewater treatment plants (TC3). Source: authors' elaboration. 